УДК: 616-053.31-089-056-07:616.8-009

ACID-ALKALINE CONDITION OF BLOOD IN DIFFERENT TYPES OF ANESTHESIOLOGICAL SUPPORT OF SURGICAL CORRECTION OF CONGENITAL DEVELOPMENTAL DEVELOPMENTS IN CHILDREN КИСЛОТНО-ЛУЖНИЙ СТАН КРОВІ ПРИ РІЗНИХ ВИДАХ АНЕСТЕЗІОЛОГІЧНОГО СУПРОВОДУ ХІРУРГІЧНОЇ КОРЕКЦІЇ ПРИРОДЖЕНИХ ВАД РОЗВИТКУ У ДІТЕЙ

\author{
Vlasov O.O./ Власов 0.0. \\ ORCID: https://orcid.org/0000-0003-1575-9872 \\ PhD / א.M.H \\ Dnepropetrovsk Regional Children's Clinical Hospital, \\ Kosmichna str., 13, Dnipro, 49100
}

Анотація.

Мета дослідження. Провести порівняльний аналіз кислотно-лужного стану в новонароджених $i$ немовлят з природженою хірургічною патологією при різних видах комбінованої анестезії.

Матеріали та методи дослідження. У ретроспективне дослідження були включені 150 новонароджених і немовлят з ПВР хірургічного профілю залежно від анестезії: I група інгаляційне + регіональне знеболення, II група - інгаляиійне + внутрішньовенне знеболювання, III група - тотальне внутрішньовенне знеболювання. Аналізувалися показники кислотнолужного стану.

Результати дослідження. Показник париіальної напруги кисню у дітей при різних видах анестезії суттєво не відрізнявся. При оціниі показників РvСО2 встановлено, щзо в I групі в порівнянні с II та III групою відзначено зниження PvCO2 під час максимально болісного, травматичного етапу та після операції. Даний показник був достовірно знижений в I групі також на початку та після операчї̈ в порівнянні з II групою. Через 24 години після хірургічного лікування РvСO2 був однаковим в групах обстежених. Показники рН венозної крові в дітей при різних видах анестезіологічного супроводу не залежали від етапів операції за виключенням I групи. Лише у даних дітей після операції рівень рН суттєво

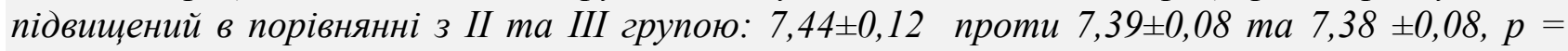
0,0094; $p=0,0084$, відповідно.

Висновки. Найбільш суттєві зміни кислотно-лужного стану відмічаються у дітей, яким анестезіологічний супровід забезпечується інгаляційним знеболюванням севораном 3 регіональною анестезією.

Ключові слова: новонароджені, немовлята, природжені вади розвитку, комбінована анестезія, кислотно-лужний стан.

\title{
Вступ
}

Природжені вади розвитку (ПВР) відносяться до патології, що найчастіше зустрічається в новонароджених та дітей першого року життя та потребують хірургічної корекції в перші години, дні життя або протягом року. Операція дозволяє провести радикальну або поступову корекцію аномалії розвитку, поліпшити стан дитини та відновити життєздатність органів $[1,2]$. Діти мають високий ризик розвитку гіпоксії органів і тканин [3]. Дихальна підтримки дитини під час операції спрямована на мінімізацію ризику виникнення гіпоксемії, гіпероксеміі, гіпокапнії, гіперкапнії та порушень кислотно-лужного стану (КЛС) крові. Своєчасна оцінка даних показників в динаміці анестезіологічного супроводу дозволяє зводити до мінімуму виникнення 
ймовірних ускладнень $[4,5]$.

\section{Основний текст}

Мета дослідження. Провести порівняльний аналіз кислотно-лужного стану в новонароджених і немовлят 3 природженою хірургічною патологією при різних видах комбінованої анестезії.

Матеріали та методи дослідження. У ретроспективне дослідження були включені 150 новонароджених і немовлят із ПВР, які отримали хірургічне лікування у 2015-2019 році.

Було сформовано 3 групи обстежених дітей залежно від типу комбінованої анестезії при хірургічній корекції аномалій: I група (50 дітей) - інгаляційна (севоран) + регіональне знеболювання; II група (50 дітей) - інгаляційна (севоран) + внутрішньовенне знеболювання (фентаніл); III група (50 дітей) тотальна внутрішньовенна анестезія 2 препаратами: знеболюючий (фентаніл) та медикаментозний сон на тлі внутрішньовенної ін'єкції гіпнотиків (20\% оксибутірат натрію). Проведено операції: торакальні, урологічні, абдомінальні.

Дослідженні проводилася за наступними етапами операції: 1) до проведення хірургічного лікування та анестезіологічного супроводу, 2) уведення дитини в наркоз, 3) травматичний етап - середина операції або максимально болісний етап хірургічного втручання, 4) післяопераційний період (протягом 1 години після транспортування дитини у відділення інтенсивної терапії), 5) через 24 години після операції.

Протягом усіх етапів досліджувалися наступні показники: концентрація водневих іонів (pH), парціальна напруга вуглекислого газу в венозній крові (PvCO2), парціальна напруга кисню (PvO2), надлишок основ крові (BE). Всі дослідження КЛС проводилися за допомогою ионоселективного іонізатора електролітів і газів крові «Medica Easy Lyte», США. Статистичну обробку результатів проводили за допомогою програмного продукту STATISTICA 6.1® (StatSoft Inc., серійний № AGAR909E415822FA).

\section{Результати дослідження}

Показник $\mathrm{PvO} 2$ у дітей при різних видах анестезії суттєво не відрізнявся. При оцінці показників PvCO2 встановлено, що в I групі в порівнянні з II та III групою відзначено зниження $\mathrm{PvCO} 2$ під час індукції анестезії, максимально болісного, травматичного етапу та після операції (табл. 2). Даний показник був достовірно знижений в I групі також на початку в порівнянні з II групою та після операції - 3 II та III групою. Через 24 години після хірургічного лікування $\mathrm{PvCO} 2$ був однаковим в групах обстежених.

Показники $\mathrm{pH}$ венозної крові в дітей при різних видах анестезіологічного супроводу не залежали від етапів операції за виключенням I групи. Лише у даних дітей після операції рівень $\mathrm{pH}$ суттєво підвищений в порівнянні з II та III

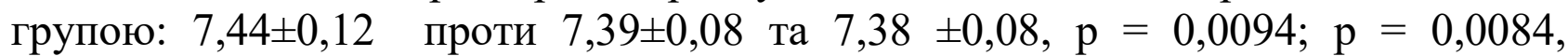
відповідно.

Показники ВЕ у венозній крові не змінювалися залежно від виду анестезії та етапу операції, за винятком дітей III групи, в якій через 24 години після операції показник ВE був значно нижчий ніж в II групі. 
Таблиця 2

Показники парціальної напруги СО2 у венозній крові (PvCO2) в дітей при різних видах анестезії залежно від етапів операції, $\mathrm{M} \pm \mathbf{m}$

\begin{tabular}{|c|c|c|c|c|}
\hline \multirow{2}{*}{ Етапи операції } & \multicolumn{2}{|c|}{ Групи обстежених дітей } & \multirow{2}{*}{ P } \\
\cline { 2 - 4 } & $\begin{array}{c}\text { I } \\
(\mathrm{n}=50)\end{array}$ & $\begin{array}{c}\text { II } \\
(\mathrm{n}=50\end{array}$ & $\begin{array}{c}\text { III } \\
(\mathrm{n}=50)\end{array}$ & \\
\hline Початок & $31,3 \pm 6,5$ & $33,8 \pm 7,1$ & $36,0 \pm 7,4$ & $\begin{array}{l}0,0724^{*} \\
0,0013^{* *} \\
0,1398^{* * *}\end{array}$ \\
\hline Індукція & $31,3 \pm 6,2$ & $36,1 \pm 6,9$ & $36,3 \pm 6,7$ & $\begin{array}{l}0,0005^{*} \\
0,0003^{* *} \\
0,8916^{* * *}\end{array}$ \\
\hline Травматичний & $30,6 \pm 6,7$ & $35,2 \pm 6,7$ & $35,9 \pm 6,7$ & $\begin{array}{l}0,001^{*} \\
0,0001^{* *} \\
0,5484^{* * *}\end{array}$ \\
\hline Після операції & $31,0 \pm 9,2$ & $36,9 \pm 8,01$ & $35,4 \pm 7,2$ & $\begin{array}{l}0,001^{*} \\
0,0109^{* *} \\
0,3079^{* * *}\end{array}$ \\
\hline $\begin{array}{c}\text { Через 24 } \\
\text { години після } \\
\text { операції }\end{array}$ & $36,4 \pm 9,8$ & $39,4 \pm 6,7$ & $38,4 \pm 7,5$ & $\begin{array}{l}0,0768^{*} \\
0,2577^{* *} \\
0,4797^{* * *}\end{array}$ \\
\hline
\end{tabular}

Примітки:

*-P між I та II групами; ** - P між I та III групами; ***_P між II та III групами.

\section{Заключення та висновки}

Найбільш суттєві зміни кислотно-лужного стану відмічаються у дітей 3 ПВР, яким оперативне втручання проводиться з анестезіологічним супровідом інгаляційним знеболюванням севораном з регіональною анестезією.

Література:

1. Kamata M. Perioperative care of infants with pyloric stenosis. Paediatr. Anaesth. 2015;25(12):1193-1206. https://doi.org/10.1111/pan.12792

2. Горбатюк О.М. Сучасний стан хірургії новонароджених в Україні та перспективи іiі розвитку. Неонатологія, хірургія та перинатальна медицина. 2011;1(1):17-20. http://nbuv.gov.ua/UJRN/Nkhpm_2011_1_1_5

3. Bednarczyk D, Makowska I, Sasiadek MM, Smigiel R. Somatic mosaicism in esophageal atresia. Am J Gastroenterology. 2014;109(12):1954-6. doi: 10.1038/ajg.2014.346.

4. Fouzas S, Priftis KN, Anthracopoulos MB. Pulse oximetry in pediatric practice. Pediatrics. 2011 Oct;128(4):740-52. doi: 10.1542/peds.2011-0271.

5. Poets C.F. Noninvasive Monitoring and Assessment of Oxygenation in Infants. Clin Perinatol. 2019;46(3): 417-433. doi: 10.1016/j.clp.2019.05.010.

Abstract.

The aim of the study. Carry out a comparative analysis of acid-base status in newborns and infants with congenital surgical pathology under different types of combined anesthesia.

Materials and methods of research. The retrospective study included 150 newborns and infants with surgical PVR depending on anesthesia: Group I - inhalation + regional anesthesia, 
Group II - inhalation + intravenous anesthesia, Group III - total intravenous anesthesia. Indicators of acid-base status were analyzed.

Research results. The rate of partial tension of oxygen in children with different types of anesthesia did not differ significantly. When assessing PvCO2 indicators, it was found that in group I in comparison with group II and III there was a decrease in PvCO2 during the most painful, traumatic stage and after surgery. This indicator was significantly reduced in group I also at the beginning and after surgery compared to group II. 24 hours after surgery, PvCO2 was the same in the groups examined. The pH of venous blood in children with different types of anesthesia did not depend on the stages of the operation with the exception of group I. Only in these children after surgery the $\mathrm{pH}$ level was significantly increased in comparison with groups II and III: $7.44 \pm 0.12$ against $7.39 \pm 0.08$ and $7.38 \pm 0.08, p=0.0094 ; p=0.0084$, respectively.

Conclusions. The most significant changes in the acid-base state are observed in children who are provided with anesthesia by inhalation anesthesia with sevorane with regional anesthesia.

Key words: newborns, infants, congenital malformations, combined anesthesia, acid-base status 